\title{
Assessing the conservation status of Mediterranean temporary ponds using biodiversity: a new tool for practitioners
}

\author{
A. Lumbreras $\cdot$ J. T. Marques $\cdot$ A. F. Belo $\cdot$ M. Cristo $\cdot$ \\ M. Fernandes • D. Galioto - M. Machado • A. Mira • \\ P. Sá-Sousa $\cdot$ R. Silva $\cdot$ L. G. Sousa $\cdot$ C. Pinto-Cruz
}

Received: 12 October 2015/Revised: 1 February 2016/Accepted: 11 February 2016/Published online: 26 February 2016

(C) Springer International Publishing Switzerland 2016

\begin{abstract}
The assessment of the habitat condition is the first step of conservation actions and several tools are available to assess wetlands. However, only a few tools are adapted to the priority habitat Mediterranean temporary ponds. Thus, our objectives were (i) to identify biological indicators associated with the different conservation status of Mediterranean temporary ponds and (ii) to create an efficient evaluation tool for non-experts using indicators of conservation
\end{abstract}

A. Lumbreras and J. Tiago Marques have contributed equally to this work.

Guest editors: Simonetta Bagella, Dani Boix, Rossella Filigheddu, Stéphanie Gascón, Annalena Cogoni / Mediterranean Temporary Ponds

Electronic supplementary material The online version of this article (doi:10.1007/s10750-016-2697-7) contains supplementary material, which is available to authorized users.

A. Lumbreras - J. T. Marques · A. F. Belo .

P. Sá-Sousa · C. Pinto-Cruz

ICAAM - Instituto de Ciências Agrárias e Ambientais

Mediterrânicas, Universidade de Évora, Núcleo da Mitra, 7002-554 Évora, Portugal

A. F. Belo · M. Fernandes - D. Galioto ·

A. Mira · P. Sá-Sousa · R. Silva · L. G. Sousa •

C. Pinto-Cruz $(\triangle)$

Departamento de Biologia, Escola de Ciências e

Tecnologia, Universidade de Évora, Ap. 94,

7002-554 Évora, Portugal

e-mail:ccruz@uevora.pt status. A total of 87 ponds were sampled in southwest Portugal to assess the presence of plants, large branchiopods, amphibians, threatened voles and bats. Ponds with favourable conservation status showed higher species richness of plants, large branchiopods and amphibians. We identified eighteen indicators for favourable ponds: 15 plants, one large branchiopod and two amphibian taxa. We propose a new tool to assess the conservation status of Mediterranean temporary ponds based on the presence of these indicators. This tool is an alternative to other common, but timeconsuming, methods and can be readily used by trained practitioners. The replication and adaptation of this tool to other regions and habitats enables the collection of comparable data and the geographical scaling-up of the assessments.

Keywords Indicator species $\cdot$ Plants $\cdot$ Large branchiopods $\cdot$ Amphibians $\cdot$ Bats $\cdot$ Voles

M. Cristo - M. Machado

CCMAR - Centro de Ciências do Mar, Universidade do Algarve, Campus de Gambelas, 8005-139 Faro, Portugal

J. T. Marques - A. Mira $\cdot$ R. Silva

Unidade de Biologia da Conservação, Departamento de Biologia, Universidade de Évora, Núcleo da Mitra, 7002-554 Évora, Portugal

A. Mira

CIBIO - Centro de Investigação em Biodiversidade e

Recursos Genéticos, Universidade de Évora, 7000-890 Évora, Portugal 


\section{Introduction}

The assessment of the habitat condition is an essential first step of conservation actions and management plans (Maes, 2013), but it is a complex and difficult task (Sala et al., 2004; Trigal et al., 2009). Recently, several tools have been developed for wetland conservation status assessment (Boix et al., 2005; Hargiss et al., 2008; Indermuehle et al., 2010); however, only a few can be adapted to the singular Mediterranean temporary ponds (Dimitriou et al., 2006; Van den Broeck et al., 2015). This particular temporary wetland type is classified as a priority freshwater habitat (3170*, NATURA 2000) under the Habitats Directive (European Commission, 2007; Ruiz, 2008), and therefore reports of the conservation status of Mediterranean temporary ponds should be presented every 6 years by each member state (Evans \& Arvela, 2011).

Mediterranean temporary ponds, which occur in shallow depressions, are unusual habitats seasonally flooded, with a short aquatic phase. They are among the most interesting ecosystems in the Mediterranean region encompassing several unique and endemic species (Rhazi et al., 2001, 2011; Grillas et al., 2004; Korn et al., 2010). This habitat is declining severely across several countries of the Mediterranean basin: $23 \%$ in Benslimane Province, Morocco, 56\% for southwest region, Portugal, and $94 \%$ in Azuaga county, Spain (Gallego-Fernández et al., 1999; Rhazi et al., 2001; Ferreira \& Beja, 2013). Mediterranean temporary ponds are extremely vulnerable habitats due to their small size, shallow depth of water, proximity to expanding urban areas, intensive agriculture, industrialization, development of tourism and their scattered and isolated distribution at a regional level. Thus, protection and conservation of the ponds are very important and appropriate management should be immediately applied to preserve such a vulnerable ecosystem (Zacharias \& Zamparas, 2010).

To achieve this goal, it is essential to translate the scientific knowledge to practitioners and to action. Ecological assessment is a topic of applied research that is particularly useful for managers. Exchanges between researchers and practitioners need to focus on the development of tools that respond to the needs of practitioners (Oertli et al., 2009), for example, tools for assessing the conservation status with small investment of time and effort (Cancela da Fonseca et al., 2008; Oertli et al., 2009). Moreover, these assessment tools can be used to monitor changes in the status of the habitats over time, under different conservation or management practices.

Although evaluation tools might focus on several types of indicators(chemical, physical and biological), biological indicators facilitate more comprehensive and accurate assessments (Angermeier \& Davideanu, 2004). They can involve a single indicator species, a set of indicators or entire assemblages/communities whose presence/absence, abundance or diversity patterns can provide information about ecological changes. This kind of indicators is commonly used to assess wetland quality (Angermeier \& Davideanu 2004; Van den Broeck et al., 2015).

Therefore, our overall aim was to establish criteria for evaluating the conservation status of Mediterranean temporary ponds. Our specific objectives were (i) to identify biological indicators associated with the different conservation status of Mediterranean temporary ponds and (ii) based on this knowledge, to create a tool that can be used by non-experts to assess the conservation status.

\section{Materials and methods}

Study area

A total of 87 Mediterranean temporary ponds were surveyed in the southwest coast of Portugal. This coastal platform runs north-south for about $100 \mathrm{~km}$ long $\times 5-15 \mathrm{~km}$ wide, ranging 50-150 $\mathrm{m}$ above sea level and is carved in Palaeozoic schist and covered by sandstone types-sands, sandstone and conglomerates—as described by Neto et al. (2007) (Fig. 1).

The climate is Mediterranean with an oceanic influence. Most rain falls from October to March, and its mean annual value ranges from $614 \mathrm{~mm}$ in the north to $456 \mathrm{~mm}$ in southern areas. Winter and summer average temperatures are 11.0 and $20.5^{\circ} \mathrm{C}$, respectively.

This region is included in the Natura 2000 Site of Conservation Interest "Costa Sudoeste" and hosts a large number of temporary ponds. The surface area of the studied temporary ponds ranges from 0.005 to 7.294 ha with an overall area of approximately 70.5 ha.

The Mediterranean temporary ponds in this area have been compatible with, and even favoured by, 


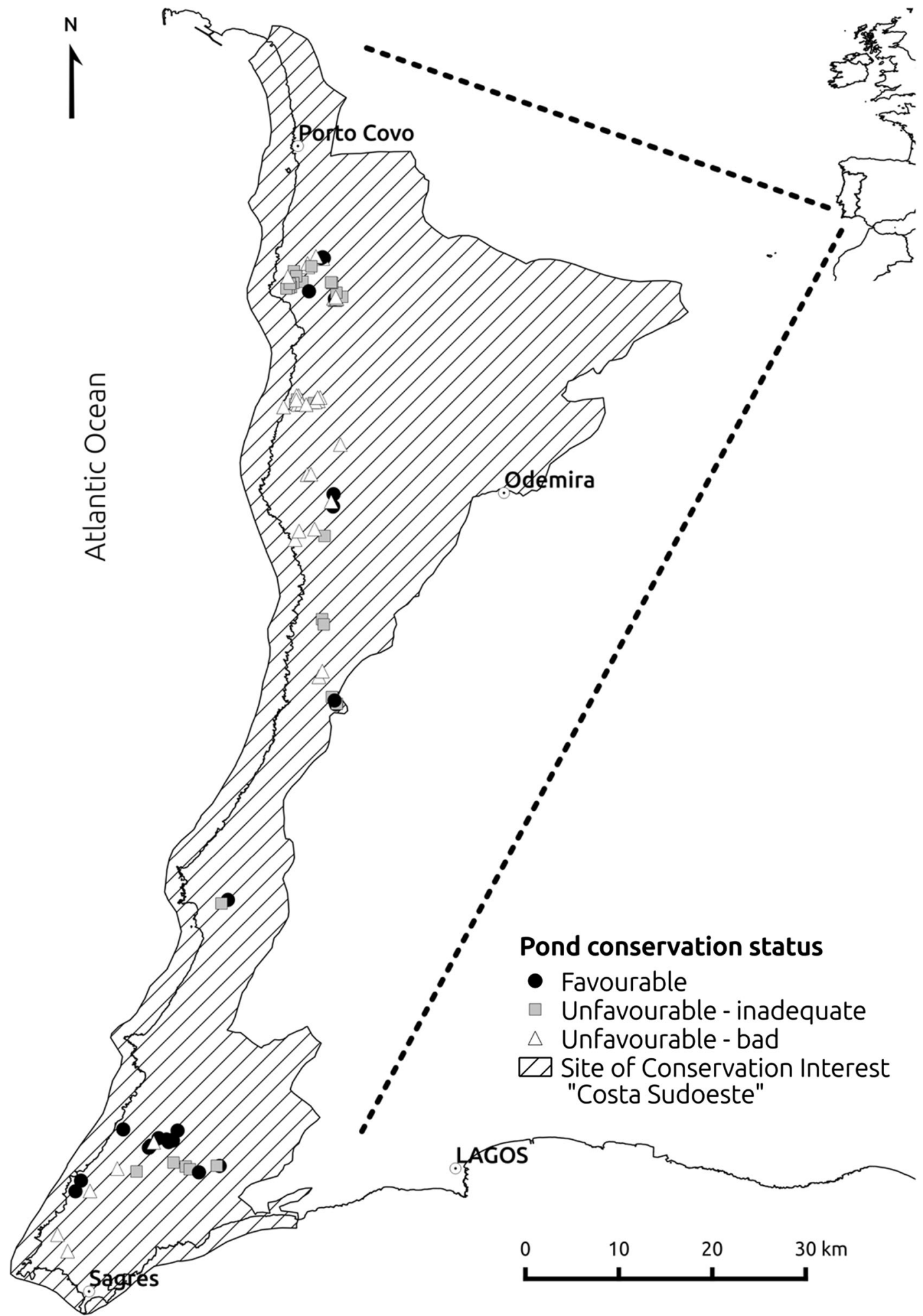

Fig. 1 Study area, location and classification of ponds 
traditional agricultural practices. Most of the land is privately owned and 12,000 ha are administrated by an irrigation plan aimed to develop agricultural activities. Thus, intensive agriculture practices such as drainage, overgrazing and fertilization are increasingly common, whereas declining traditional land uses include extensive grazing and agriculture.

\section{Data collection}

We conducted fieldwork for the different biological groups in 2014 and 2015 during Winter and Spring, depending on the conditions needed for the sampling of each species group.

The presence of plant species was recorded using $4 \mathrm{~m}^{2}$ plots. In each pond, we surveyed a variable number of plots until we reached plateau of the number of the species and no new species was added to the sample. Plant nomenclature follows Flora Iberica (Castroviejo et al., 1986-2008) and Nova Flora de Portugal (Franco \& Rocha Afonso, 1994). The presence of large branchiopod species was recorded, as much as possible, 2 to 3 weeks after the beginning of hydroperiod, due to the very short life cycles of some Anostraca species. In each pond, several samples were taken with a hand net $(1 \mathrm{~mm}$ squared mesh) that has an opening of $730 \mathrm{~cm}^{2}$. This sampling was conducted in a way that allows coverage of all microhabitats, from shallow marginal areas to deeper central areas. Sorting was performed on site, and all individuals that could not be identified due to their size/age, were collected, fixed and brought to the laboratory for posterior and accurate identification. We surveyed amphibians using dip net techniques, through three blind sweeps according to microhabitat representativeness. Secondarily, we walked along pond margins for 10 min trying to find adults. Captured individuals (larvae, juveniles and adults) were identified to species level and returned to water at the end of the sampling. The presence of the threatened vole species, Microtus cabrerae and Arvicola sapidus, was assessed by searching and identifying their droppings (Pita et al., 2006). Doubtful droppings were genetically identified following the procedures described in Paupério et al. (2012). We surveyed bats on each pond using automatic ultrasound detectors (D500 $\times$ Pettersson Elektronic $\mathrm{AB}$ ), which can record the echolocation of passing bats. Detectors were set up on a tripod and placed on the pond area during the first $3 \mathrm{~h}$ of the night. The automatic stations recorded a 3 s. sample for each bat pass. Ultrasound recordings were then identified to species or sonotypes using sound analysis.

Pond conservation status assessment

We assessed conservation status of each pond using well-defined criteria selected from a comprehensive review of the literature (Grillas et al., 2004; Sala et al., 2004; Dimitriou et al., 2006; Fennessy et al., 2007; Stamati et al., 2008; Maes, 2013). This information was integrated and adapted using knowledge on the habitat and the region (Pinto-Cruz et al., 2009, 2011). Hence, the conservation status of each pond was assessed considering four parameters: (i) Topography-which is closely linked to the adequate hydroperiod, characterised by the timing and length of flooding, and water column depth; changes in hydroperiod have important effects in temporary waters, as they may change the pattern and strength of biotic interactions (Zacharias \& Zamparas, 2010); (ii) Vegetation structure-a key parameter related to the habitat definition and presence of an ecological gradient, assessed by the number of vegetation belts. In this region, a well-preserved pond has three different vegetation belts (Pinto-Cruz et al., 2009); (iii) Impact of human activities - overall impact of the common anthropogenic activity on the condition of ponds (overgrazing, excavation, agriculture, hydrologic disturbance and tourism). The magnitude of a given disturbance is often more significant than the type of disturbance (Kantrud et al., 1989); and (iv) Trend of the pond area-the most important habitat feature for the conservation of a pond; if the pond area is stable or declining and in that case at which rate. Each of these parameters was scored into three categories according to field surveys and expert knowledge (Table 1).

We combined the categories of the four parameters to classify each pond into one of the three classes of conservation status proposed by Evans \& Arvela (2011): favourable, unfavourable-inadequate or unfavourable-bad (Table 2). In our study, the criteria to assess the parameters are adapted specifically for Mediterranean temporary pond habitat and defined in a way that can be straightforwardly repeated in other areas. 
Data analysis

Species richness of each biological group, except voles, was compared between pond condition categories using ANOVA or Kruskal-Wallis tests, depending on the non-violation of the statistical assumptions. Tukey's HSD was performed, when necessary, to identify significant differences between groups.

We used the indicator species method-IndVal-to identify species with predictive value for the pond conservation status groups (Dufrene \& Legendre, 1997; De Cáceres \& Legendre, 2009). This method is often used to select indicative taxa associated with different types of sites (Heino et al., 2005; Urban et al., 2012). The studied sites can be grouped a priori and their classification should be independent from the indicator species data. A good indicator species is mostly found in one group of the site classification and present at most sites belonging to that group. The indicator value of a species varies between 0 and 1, when all the individuals of one species are observed at all sites belonging to a single group (Legendre, 2012). This approach allows the comparison of indicator value between unrelated taxa because it is calculated independently of the other species present in the assemblage (McGeoch \& Chown, 1998; Legendre, 2012). Specific indicator values were obtained using Ginkgo (De Cáceres et al., 2007) with 99,999 permutations.

We also used the well-known Pearson's phi coefficient $(\Phi)$ to assess the association between species presence-absence and pond conservation status categories (Chytrý et al., 2002; De Cáceres \& Legendre, 2009). This coefficient takes values from -1 to +1 , where positive values indicate that the species and the conservation status category co-occur more frequently than would be expected by chance. Larger values indicate a greater degree of joint fidelity. The value 1 indicates that the species and conservation status category are faithful to each other (Chytrý et al., 2002). Pearson's phi coefficients were obtained using Ginkgo (De Cáceres et al., 2007).

To calculate the minimum number of indicator species that discriminate ponds of different conditions, we recorded the total number of indicators in each pond. Depending on the number of indicators taken into account to classify the conservation status of ponds, we calculated the percentage of ponds with favourable conservation status assessed as unfavourable (Error I) and the percentage of ponds with unfavourable conservation status assessed as favourable (Error II) from the minimum to maximum number of indicators. A graphical analysis was performed to find the number of indicators that minimised both type I and II errors.

\section{Results}

The Mediterranean temporary ponds were classified according to the parameters into conservation status categories: favourable ( $n=22$ ponds), unfavourableinadequate ( $n=27$ ponds) and unfavourable-bad ( $n=38$ ponds) (Fig. 1).

During the biodiversity surveys, we identified 248 plant species, 6 large branchiopod species (3 Anostraca, 1 Notostraca, 2 Spinicaudata), 12 amphibian species (4 Caudata and 8 Anura), two threatened voles and 14 bat species or sonotypes (Online Resource 1). Richness of plants, large branchiopods and amphibians was significantly higher in ponds with favourable

Table 1 Parameters and score categories to assess the Mediterranean temporary ponds. Examples of the features are given for each category

\begin{tabular}{|c|c|c|c|}
\hline \multirow[t]{2}{*}{ Parameter } & \multicolumn{3}{|l|}{ Category } \\
\hline & Good & Poor & $\mathrm{Bad}$ \\
\hline Topography & $\begin{array}{l}\text { Typical pond depression (smooth slopes, } \\
\text { adequate depth, without ditches) }\end{array}$ & $\begin{array}{l}\text { Very shallow depression, } \\
\text { and few and small ditches }\end{array}$ & $\begin{array}{l}\text { Almost no depression, or too deep } \\
\text { depression; steep slopes; deep ditches }\end{array}$ \\
\hline $\begin{array}{l}\text { Vegetation } \\
\text { structure }\end{array}$ & Three vegetation belts & Two vegetation belts & One vegetation belt \\
\hline $\begin{array}{l}\text { Human } \\
\text { impact }\end{array}$ & $\begin{array}{l}\text { Low (e.g. traditional farming, no } \\
\text { ploughing) }\end{array}$ & $\begin{array}{l}\text { Moderate (e.g. abandonment } \\
\text { or shallow ploughing) }\end{array}$ & $\begin{array}{l}\text { High to very high (e.g. intensive farming, } \\
\text { pond deep ploughing) }\end{array}$ \\
\hline Area trend & Stable & Decreasing & Severely decreasing \\
\hline
\end{tabular}


Table 2 Pond conservation status classification and combinations of the parameters used to assess its status

\begin{tabular}{ll}
\hline Pond conservation status & Parameter combinations \\
\hline Favourable & At least two parameters classified as good and no parameters classified as bad \\
Unfavourable-inadequate & All the other combinations not mentioned above and below \\
Unfavourable-bad & Vegetation structure with only 1 belt or more than one parameter classified as bad \\
\hline
\end{tabular}

conservation status (all values $P<0.0001$, Fig. 2); on average, species richness was approximately twofold in favourable ponds compared to other categories $(1.5$ times higher for plants, 2.7 times for large branchiopods and 2.1 for amphibians). In contrast, we did not find significant differences for bat richness $(P$ value 0.351 , Fig. 2 ).

Indicator species analysis shows that 18 species are associated to ponds with favourable conservation status: 15 plants, one large branchiopod and two amphibians. These species also correspond to those with higher $\Phi$ values for favourable conservation status group (Table 3). Bat and vole species had low indicator values. It is noteworthy that some species were exclusive of favourable ponds but were present in very few (e.g. Hypsugo savii). Other species related to favourable ponds, such as Arvicola sapidus, were also present evenly in the other conservation status categories. No indicator species were found for pond unfavourable conservation categories: unfavourableinadequate and unfavourable-bad. Moreover, in both categories species had low $\Phi$ values $(\Phi<0.35)$.

The five species of Myosotis genus found in the studied ponds were assigned to favourable conservation status group by indicator species analysis and they are positively correlated to the same group according to $\Phi$ values (Table 4). Myosotis genus as a variable is significantly associated to ponds with favourable conservation status group with a higher IndVal than any Myosotis species. This genus has also a high $\Phi$ value. Similar results were obtained for the Isoetes genus (plants) and the order Anostraca (large brachiopods), both with three species (Table 4).

The graphical analysis shows that both type I and II errors are minimised at six indicators (Fig. 3). Thus, pond conservation status is assessed depending on the number of indicators that this habitat hosts, and therefore when at least six of the 18 indicators are present in a pond it can be classified as favourable.

\section{Discussion}

Indicators of conservation status

It is a general consensus that high richness is needed to maintain multiple functioning (Hector \& Bagchi, 2007; Isbell et al., 2011) and that species loss can be a major driver of ecosystem change (Hooper et al., 2012). Habitats in a favourable conservation status have higher potential to supply ecosystem services and host a richer biodiversity than habitats in unfavourable conservation status (Maes et al., 2012). Our results revealed that favourable ponds have a higher number of species than less preserved ponds; this pattern was found for most of the studied species groups, i.e. plants, large branchiopods and amphibians. In disturbed wetlands, species richness is one of the most affected community parameters, particularly for groups highly dependent on these ecosystems (Hill \& Keddy, 1992; Kantrud \& Newton, 1996; SandJensen et al., 2000; Waterkeyn et al., 2008; Trigal et al., 2009; Bouahim et al., 2010). Life cycles of some species of plants and amphibians are strictly dependent on temporary wetlands (Grillas et al., 2004; Ferreira \& Beja, 2013), and most of the large branchiopods are exclusive inhabitants of temporary water habitats (Alonso, 1996; Cancela da Fonseca et al., 2008). In fact, plant richness has been already related to conservation status of wetlands (Kantrud \& Newton, 1996; Serrano \& Zunzunegui, 2008; Bouahim et al., 2010). Cancela da Fonseca et al. (2008) also classified ponds with higher species richness of large branchiopods and amphibians with higher conservation value.

Human disturbance also modifies species composition of Mediterranean temporary ponds (Rhazi et al., 2001; Bagella et al., 2010; Bouahim et al., 2010; Van den Broeck et al., 2015), which allows to identify indicator species of their conservation status. Our 
Fig. 2 Richness of plants, large branchiopods (LB), amphibians and bats in favourable $(\mathrm{F})$,

unfavourable-inadequate (U-I) or unfavourable-bad (U-B) ponds

Table 3 Indicator species for favourable Mediterranean temporary ponds
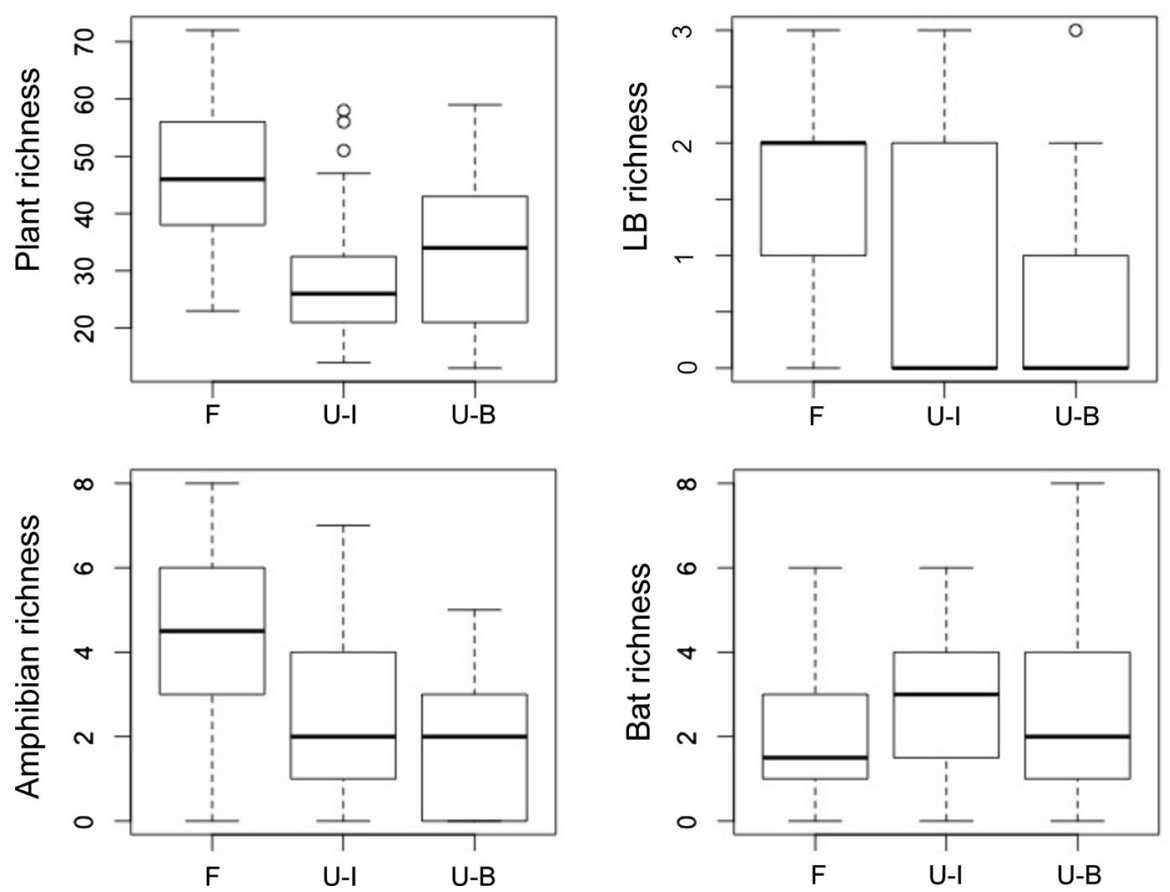

\begin{tabular}{|c|c|c|c|c|}
\hline \multirow[t]{2}{*}{ Species } & \multirow[t]{2}{*}{ Group } & \multicolumn{2}{|c|}{ Indicator species } & \multirow{2}{*}{$\begin{array}{l}\text { Pearson's phi } \\
\text { coefficient } \\
\Phi\end{array}$} \\
\hline & & IndVal & $P$ value & \\
\hline Eryngium corniculatum & Plants & 0.787 & $<0.0001$ & 0.631 \\
\hline Myosotis debilis & Plants & 0.709 & $<0.0001$ & 0.493 \\
\hline Pleurodeles waltl & Amphibians & 0.672 & $<0.0001$ & 0.468 \\
\hline Illecebrum verticillatum & Plants & 0.658 & $<0.0001$ & 0.467 \\
\hline Hyacinthoides vicentina & Plants & 0.645 & $<0.0001$ & 0.452 \\
\hline Isoetes setaceum & Plants & 0.645 & $<0.0001$ & 0.537 \\
\hline Polypogon maritimus & Plants & 0.641 & $<0.0001$ & 0.486 \\
\hline Carum verticillatum & Plants & 0.631 & $<0.0001$ & 0.486 \\
\hline Ranunculus peltatus & Plants & 0.630 & 0.0003 & 0.412 \\
\hline Tanymastix stagnalis & Large branchiopods & 0.623 & 0.0005 & 0.395 \\
\hline Cuscuta planiflora & Plants & 0.603 & $<0.0001$ & 0.547 \\
\hline Exaculum pusillum & Plants & 0.603 & $<0.0001$ & 0.547 \\
\hline Triturus pygmaeus & Amphibians & 0.602 & 0.0001 & 0.436 \\
\hline Chaetopogon fasciculatus & Plants & 0.591 & 0.0002 & 0.421 \\
\hline Chamaemelum nobile & Plants & 0.546 & 0.0007 & 0.393 \\
\hline Littorella uniflora & Plants & 0.515 & 0.0009 & 0.41 \\
\hline Agrostis castellana & Plants & 0.499 & 0.0008 & 0.411 \\
\hline Solenopsis laurentia & Plants & 0.499 & 0.0008 & 0.411 \\
\hline
\end{tabular}

results revealed 18 species as indicators of favourable conservation status. In fact, both analyses (IndVal and Pearson's phi coefficient) highlighted the same set of species, therefore the proposed indicators are robust and highly sensitive to habitat disturbances. Individually, the presence or absence of an indicator species 
Table 4 Indicator groups for favourable Mediterranean temporary ponds. Groups (genera and order) in bold

\begin{tabular}{|c|c|c|c|}
\hline \multirow[t]{2}{*}{ Taxa } & \multicolumn{2}{|c|}{ Indicator species } & \multirow{2}{*}{$\begin{array}{l}\text { Pearson's phi } \\
\text { coefficient } \\
\Phi\end{array}$} \\
\hline & IndVal & $P$ value & \\
\hline Myosotis & 0.72 & 0.0001 & 0.484 \\
\hline Myosotis debilis & 0.71 & 0.0001 & 0.493 \\
\hline Myosotis laxa & 0.51 & 0.0095 & 0.311 \\
\hline Myosotis discolor & 0.30 & 0.0700 & 0.264 \\
\hline Myosotis retusifolia & 0.24 & 0.2300 & 0.125 \\
\hline Myosotis welwitschi & 0.24 & 0.2400 & 0.125 \\
\hline Isoetes & 0.67 & 0.0001 & 0.418 \\
\hline Isoetes setaceum & 0.65 & 0.0001 & 0.537 \\
\hline Isoetes velatum & 0.54 & 0.0046 & 0.331 \\
\hline Isoetes histrix & 0.42 & 0.1700 & 0.166 \\
\hline Anostraca & 0.66 & 0.0004 & 0.404 \\
\hline Tanymastix stagnalis & 0.62 & 0.0005 & 0.395 \\
\hline Branchipus cortesi & 0.55 & 0.0053 & 0.332 \\
\hline Chirocephalus diaphanus & 0.29 & 0.2500 & 0.155 \\
\hline
\end{tabular}
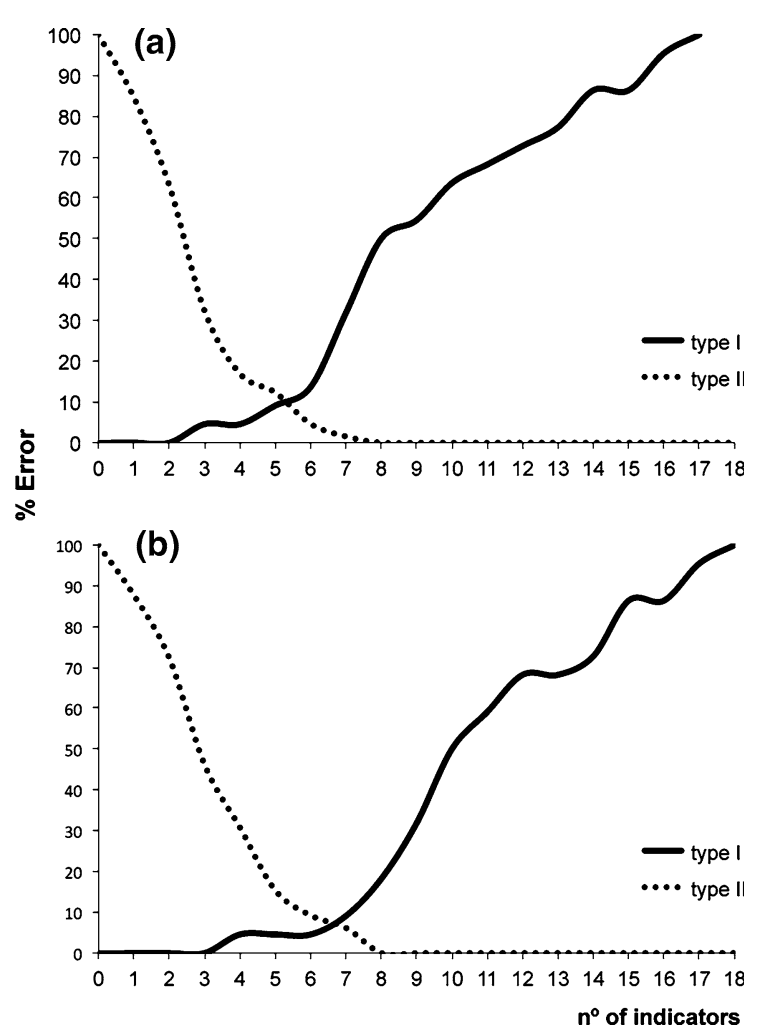

Fig. 3 Error I and II using species (a), and species and groups (b) as indicators to assess conservation status of ponds

may reflect specific habitat changes. However, the use of a set of indicator species is preferable because of their responses to different types of stressors. Ideally, the set of indicators should represent key information about structure, function and composition providing a measure of coverage of the ecological gradients across the systems (Dale \& Beyeler, 2001). In our case, the resulting set is composed by different biological groups: plants, large branchiopods and amphibians. Considering flora and fauna groups simultaneously could reveal a more complete view of the habitat and result in a more complete understanding of ecosystem functionality (Bagella et al., 2010).

In our set of indicators, plants were the most represented biological group, probably because they are extremely sensitive to habitat disturbances (Rhazi et al., 2001, 2006; Crosslé \& Brock, 2002; Bagella et al., 2010; Bouahim et al., 2010). Plant composition in wetlands is influenced mainly by hydrologic regime (Casanova \& Brock, 2000; Della Bella et al., 2008) and water quality (Lumbreras et al., 2013; Rosset et al., 2014; Chappuis et al., 2015). The disturbance of these two factors by drainage, excavation, irrigation or eutrophication may have severe impacts on plant species in wetlands and specifically in Mediterranean temporary ponds (Rhazi et al., 2001; Serrano \& Zunzunegui, 2008; Lumbreras et al., 2012; Rosset et al., 2014).

Many plant indicators of favourable condition in our analyses correspond to characteristic species of Mediterranean temporary ponds (Eryngium corniculatum, Illecebrum verticillatum, Isoetes setaceum, Chaetopogon fasciculatus, Exaculum pusillum, 
Hyacinthoides vicentina, Myosotis debilis, Solenopsis laurentia, Carum verticillatum, Littorella uniflora and Polypogon maritimus) (ALFA, 2004; Grillas et al., 2004; European Commission, 2007; Pinto-Cruz et al., 2009). This temporary habitat often houses highly specialised species (Bouahim et al., 2014) adapted to living under extreme environmental conditions (Grillas et al., 2004). However, these plants are not tolerant to habitat disturbances that modify the existing ecological gradients (Rhazi et al., 2001, 2006). Four non-characteristic pond plants were also selected as indicators of favourable status. Their high indicator value is likely related to their auto-ecology; two of these species have been associated with good water quality (Ranunculus peltatus-Lumbreras et al., 2013) and with groundwater chemistry (Agrostis castellana-González-Bernáldez, 1992).

We also found two pond-breeding amphibians associated with favourable ponds, both newts. Triturus pygmaeus prefers well-structured Mediterranean temporary ponds with larger area, higher depth, rich in aquatic vegetation and with the watershed not ploughed (Beja \& Alcazar, 2003; Jakob et al., 2003; Gómez-Rodríguez et al., 2009). Although the early breeder Pleurodeles waltl is tolerant to visit disturbed ponds and small reservoirs (Ferreira \& Beja, 2013), often favourable Mediterranean temporary ponds are the only water bodies available in the study area that offer good breeding conditions, since ponds under the most intensive land uses showed lower prevalence of P. waltl (Beja \& Alcazar, 2003).

Bat and vole species had low indicator values. Bats have been recognised as potential bioindicators of habitat change (Jones et al., 2009), but probably other ecological factors, such as distance to roosts or trees and the presence of water, play a more relevant role on species presence in ponds than the conservation status of these habitats. Also, the higher mobility of both voles and bats may contribute to the weak association found between the presence of these species and the conservation status of studied ponds.

We found one large branchiopod species as an indicator of favourable ponds, Tanymastix stagnalis. Its presence is negatively correlated with turbidity, conductivity, ploughing intensity and iron content in water (Cancela da Fonseca et al., 2008). This species can therefore be considered as a stenoic species (García-de-Lomas et al., 2015) because of its low tolerance to changes on these abiotic factors. Thus, it can be used as a reliable indicator for the conservation status of Mediterranean temporary ponds.

Advantages and limitations of the assessment tool

Although species richness - of plants, large branchiopods and amphibians - was related to favourable ponds, this parameter is often very time consuming and requires expert knowledge. For each biological group, the entire community must be surveyed, implying the identification of a large number of species that sometimes can be challenging. Efficient assessment tools should not require expert application (Stork et al., 1997; Caro, 2010). A good indicator needs to be easily measured (Dale \& Beyeler, 2001) and identifiable by non-systematists (Lawton et al., 1998; Gardner et al., 2008).

As an alternative to measuring species richness, we suggest a new tool for the quick assessment of the conservation status of Mediterranean temporary ponds, which can be applied by surveying only a set of 18 indicator species. However, species identifications, which are often difficult and time consuming, may not always be necessary (Van den Broeck et al., 2015) since it has been shown for some groups that considering only higher taxonomic levels already allows for the monitoring of water bodies (Garcia Criado \& Fernandez Alaez, 1995; Oertli et al., 2005; Gutiérrez-Estrada \& Bilton, 2010). In fact, species groups are used far more commonly than a single species to monitor the effects of ecological disturbance (Caro, 2010). Therefore, we also propose a simplified version of the pond assessment tool, which uses some indicators of higher order taxa such as, Myosotis genus, Isoetes genus and Anostraca order, instead of the corresponding indicator species. This version, using a set of 15 species, 2 genus and 1 order, is easier to use because taxa identification becomes less demanding, while keeping the conservation assessment robust (high IndVals and $\Phi$ ) and accurate (similar type I and II errors).

To use this assessment tool requires a minimum of two sampling campaigns a year in different seasons: (i) 2-3 weeks after the beginning of the hydroperiod for surveying large branchiopods and (ii) in early spring for surveying plants and amphibians. The timing of sampling greatly determines which taxa will be encountered. Due to the high animal and plant species turnover, multiple sampling campaigns give in 
most cases an integrated view of the community structure and cover the temporal variability of this fluctuating system (Boix et al., 2005; Van den Broeck et al., 2015).

We classified Mediterranean temporary ponds into three conservation categories because moderately impacted habitats must be taken into account and not just minimally impacted and heavily impacted habitats (Kantrud \& Newton, 1996). But, the proposed tool only allows to separate favourable ponds from the two unfavourable categories (inadequate and bad) because of the lack of indicators for these lower categories. This could be explained by the multiple causes of disturbance that can reduce the conservation status of ponds, which can result in strikingly different ecological scenarios, e.g. excavated and drained ponds have high levels of disturbance but with very different ecological outcomes. Thus, species composition of unfavourable ponds is likely different depending on the type of degradation, deeming unfeasible the search for common indicators.

This habitat has extreme inter-annual dynamic of the conditions and it is subject to increasing human pressures. All together, these factors point out that monitoring should be done frequently due to the rapid habitat degradation and the high disappearance rate. This fact highlights the importance of a practical tool that can be applied by non-experts in Mediterranean temporary ponds but trained in the recognition of the 18 indicators. Furthermore, this set of indicators could be used for environmental monitoring, to track the improvement of restored or reclaimed ponds and to identify trends in condition over time.

This tool is designed to be applied in the Iberian Peninsula SW region. The overall species composition of Mediterranean temporary ponds varies in different regions, thus the set of indicators may differ. However, this tool can be adapted and calibrated for other geographical regions since these processes entail expert knowledge. A priori habitat classification is difficult and often involves in-depth knowledge of the habitat. Moreover, the evaluation of the results of this tool needs to be careful. The replication of this tool approach will gather comparable data across different regions or different state members, for this specific habitat. The integration of these comparable results may allow us to scale up these assessments and to report data at higher spatial scales-local, regional and national-ensuring the homogeneity of criteria assessment. In our study, the criteria to assess the parameters are adapted specifically for Mediterranean temporary pond habitat but they are defined in a way that can be straightforwardly reproduced for other temporary aquatic systems.

\section{Conclusion}

We provide a useful tool for the assessment of conservation status of Mediterranean temporary ponds based on a set of 18 indicators. Its rapid and easy application allows saving time, costs and human resources. Specifically, this tool was designed to be used by trained practitioners and non-experts. In its present form, this tool can only be applied in southwest Portugal, but the protocol for identifying ecological indicators can be used in other geographical regions and other habitats taking into account that the design and interpretation process must be carried out by experts in the area and habitat.

Acknowledgments We would like to thank the financial support of the LIFE Charcos project (LIFE12 NAT/PT/000997), from the European Union LIFE programme. Edgar Gomes, Núria Salvador, Cristina Baião, Joana Silva and Pedro Costa provided invaluable help during data collection. In order to conduct this research, in compliance with all laws and regulations for Portugal, we thank Instituto da Conservação da Natureza e Florestas (ICNF) for the collector's permits.

\section{References}

ALFA, 2004. Tipos de Habitat Naturais e Semi-Naturais do Anexo I da Directiva 92/43/CEE (Portugal continental): Fichas de Caracterização Ecológica e de Gestão para o Plano Sectorial da Rede Natura 2000.

Alonso, M., 1996. Fauna Iberica - Crustacea, Branchiopoda. In Ramos, M. A. (ed.), Fauna Iberica - Volume 7. Museo Nacional de Ciencias Naturales, CSIC, Madrid.

Angermeier, P. L. \& G. Davideanu, 2004. Using fish communities to assess streams in Romania: initial development of an index of biotic integrity. Hydrobiologia 511: 65-78.

Bagella, S., S. Gascón, M. C. Caria, J. Sala, M. A. Mariani \& D. Boix, 2010. Identifying key environmental factors related to plant and crustacean assemblages in Mediterranean temporary ponds. Biodiversity and Conservation 19: 1749-1768.

Beja, P. \& R. Alcazar, 2003. Conservation of Mediterranean temporary ponds under agricultural intensification: an evaluation using amphibians. Biological Conservation 114: 317-326.

Boix, D., S. Gascón, J. Sala, M. Martinoy, J. Gifre \& X. D. Quintana, 2005. A new index of water quality 
assessment in Mediterranean wetlands based on crustacean and insect assemblages: the case of Catalunya (NE Iberian peninsula). Aquatic Conservation: Marine and Freshwater Ecosystems 15: 635-651.

Bouahim, S., L. Rhazi, B. Amami, N. Sahib, M. Rhazi, A. Waterkeyn, A. Zouahri, F. Mesleard, S. D. Muller \& P. Grillas, 2010. Impact of grazing on the species richness of plant communities in Mediterranean temporary pools (western Morocco). Comptes Rendus - Biologies 333: 670-679.

Bouahim, S., L. Rhazi, B. Amami, A. Waterkeyn, M. Rhazi, E.R. Saber, A. Zouahri, M. Van den Broeck, S. D. Muller, L. Brendonck \& P. Grillas, 2014. Unravelling the impact of anthropogenic pressure on plant communities in Mediterranean temporary ponds. Marine \& Freshwater Research 65: 918-929.

Cancela da Fonseca, L., M. Cristo, M. Machado, J. Sala, J. Reis, R. Alcazar \& P. Beja, 2008. Mediterranean temporary ponds in Southern Portugal: key faunal groups as management tools? Pan-American Journal of Aquatic Sciences 3: 304-320.

Caro, T. M., 2010. Conservation by Proxy: Indicator, Umbrella, Keystone, Flagship, and Other Surrogate Species. Island Press, Washington.

Casanova, M. T. \& M. A. Brock, 2000. How do depth, duration and frequency of flooding influence the establishment of wetland plant communities? Plant Ecology 147: 237-250.

Castroviejo S. (coord. gen.), 1986-2008. Flora Ibérica, 1-8, 10-15, 17-18, 21. Real Jardín Botánico, CSIC, Madrid.

Chappuis, E., A. Lumbreras, E. Ballesteros \& E. Gacia, 2015. Deleterious interaction of light impairment and organic matter enrichment on Isoetes lacustris (Lycopodiophyta, Isoetales). Hydrobiologia 760: 145-158.

Chytrý, M., L. Tichý, J. Holt \& Z. Botta-Dukát, 2002. Determination of diagnostic species with statistical fidelity measures. Journal of Vegetation Science 13: 79-90.

Crosslé, K. \& M. A. Brock, 2002. How do water regime and clipping influence wetland plant establishment from seed banks and subsequent reproduction? Aquatic Botany 74: 43-56.

Dale, V. H. \& S. C. Beyeler, 2001. Challenges in the development and use of ecological indicators. Ecological Indicators 1: 3-10.

De Cáceres, M. \& P. Legendre, 2009. Associations between species and groups of sites: indices and statistical inference. Ecology 90: 3566-3574.

De Cáceres, M., F. Oliva, X. Font \& S. Vives, 2007. Ginkgo, a program for non-standard multivariate fuzzy analysis. Advances in Fuzzy Sets and Systems 2: 41-56.

Della Bella, V., M. Bazzanti, M. G. Dowgiallo \& M. Iberite, 2008. Macrophyte diversity and physico-chemical characteristics of Tyrrhenian coast ponds in central Italy: implications for conservation. Hydrobiologia 597: 85-95.

Dimitriou, E., I. Karaouzas, N. Skoulikidis \& I. Zacharias, 2006. Assessing the environmental status of Mediterranean temporary ponds in Greece. Annales de Limnologie International Journal of Limnology 42: 33-41.

Dufrene, M. \& P. Legendre, 1997. Species assemblages and indicator species: the need for a flexible asymmetrical approach. Ecological Monographs 67: 345-366.
European Commission, 2007. The Interpretation Manual of European Union Habitats. European Commission, Brussels.

Evans, D. \& M. Arvela, 2011. Assessment and reporting under Article 17 of the Habitats Directive. Explanatory Notes \& Guidelines for the period 2007-2012. European Topic Centre on Biological Diversity.

Fennessy, M. S., A. D. Jacobs \& M. E. Kentula, 2007. An evaluation of rapid methods for assessing the ecological condition of wetlands. Wetlands 27: 543-560.

Ferreira, M. \& P. Beja, 2013. Mediterranean amphibians and the loss of temporary ponds: are there alternative breeding habitats? Biological Conservation 165: 179-186.

Franco, J. A. \& M. Rocha Afonso, 1994. Nova Flora de Portugal (Continente e Açores), Vol. III. Escolar Editora, Lisboa.

Gallego-Fernández, J. B., M. R. García-Mora \& F. GarcíaNovo, 1999. Small wetlands lost: a biological conservation hazard in Mediterranean landscapes. Environmental Conservation 26: 190-199.

Garcia Criado, F. \& M. Fernandez Alaez, 1995. Aquatic Coleoptera (Hydraenidae and Elmidae) as indicators of the chemical characteristics of water in the Orbigo River basin (N-W Spain). Annales de Limnologie 31: 185-199.

García-de-Lomas, J., J. Sala \& M. Alonso, 2015. Orden Spinicaudata. Revista IDE@-SEA 68: 1-11.

Gardner, T. A., J. Barlow, I. S. Araujo, T. C. Avila-Pires, A. B. Bonaldo, J. E. Costa, M. C. Esposito, L. V. Ferreira, J. Hawes, M. I. M. Hernandez, M. S. Hoogmoed, R. N. Leite, N. F. Lo-Man-Hung, J. R. Malcolm, M. B. Martins, L. A. M. Mestre, R. Miranda-Santos, W. L. Overal, L. Parry, S. L. Peters, M. A. Ribeiro-Junior, M. N. F. da Silva, C. da Silva Motta \& C. A. Peres, 2008. The cost-effectiveness of biodiversity surveys in tropical forests. Ecology Letters 11: 139-150.

Gómez-Rodríguez, C., C. Díaz-Paniagua, L. Serrano, M. Florencio \& A. Portheault, 2009. Mediterranean temporary ponds as amphibian breeding habitats: the importance of preserving pond networks. Aquatic Ecology 43: 1179-1191.

González-Bernáldez, F., 1992. Ecological aspects of wetland/groundwater relationships in Spain. Limnetica 8: 11-26.

Grillas, P., P. Gauthier, N. Yavercovski \& C. Perennou, 2004. Mediterranean Temporary Pools Volume 1 - Issues Relating to Conservation, Functioning and Management. Station biologique de la Tour du Valat, Arles.

Gutiérrez-Estrada, J. C. \& D. T. Bilton, 2010. A heuristic approach to predicting water beetle diversity in temporary and fluctuating waters. Ecological Modelling 221: 1451-1462.

Hargiss, C. L. M., E. S. DeKeyser, D. R. Kirby \& M. J. Ell, 2008. Regional assessment of wetland plant communities using the index of plant community integrity. Ecological Indicators 8: 303-307.

Hector, A. \& R. Bagchi, 2007. Biodiversity and ecosystem multifunctionality. Nature 448: 188-190.

Heino, J., J. Parviainen, R. Paavola, M. Jehle, P. Louhi \& T. Muotka, 2005. Characterizing macroinvertebrate assemblage structure in relation to stream size and tributary position. Hydrobiologia 539: 121-130. 
Hill, N. M. \& P. A. Keddy, 1992. Prediction of rarities from habitat variables: coastal plain plants on Nova Scotian lakeshores. Ecology 73: 1852-1859.

Hooper, D. U., E. C. Adair, B. J. Cardinale, J. E. K. Byrnes, B. A. Hungate, K. L. Matulich, A. Gonzalez, J. E. Duffy, L. Gamfeldt \& M. I. O’Connor, 2012. A global synthesis reveals biodiversity loss as a major driver of ecosystem change. Nature 486: 105-108.

Indermuehle, N., S. Angélibert, V. Rosset \& B. Oertli, 2010. The pond biodiversity index "IBEM": a new tool for the rapid assessment of biodiversity in ponds from Switzerland. Part 1. Index development. Limnetica 29: 93-104.

Isbell, F., V. Calcagno, A. Hector, J. Connolly, W. S. Harpole, P. B. Reich, M. Scherer-Lorenzen, B. Schmid, D. Tilman, J. van Ruijven, A. Weigelt, B. J. Wilsey, E. S. Zavaleta \& M. Loreau, 2011. High plant diversity is needed to maintain ecosystem services. Nature 477: 199-202.

Jakob, C., G. Poizat, M. Veith, A. Seitz \& A. J. Crivelli, 2003. Breeding phenology and larval distribution of amphibians in a Mediterranean pond network with unpredictable hydrology. Hydrobiologia 499: 51-61.

Jones, G., D. S. Jacobs, T. H. Kunz, M. R. Willig \& P. A. Racey, 2009. Carpe noctem: the importance of bats as bioindicators. Endangered Species Research 8: 93-115.

Kantrud, H. A., G. L. Krapu \& G. A. Swanson, 1989. Prairie Basin Wetlands of the Dakotas: a community profile. Biological, Report. 85.

Kantrud, H. A. \& W. E. Newton, 1996. A test of vegetationrelated indicators of wetland quality in the prairie pothole region. Journal of Aquatic Ecosystem Health 5: 177-191.

Korn, M., A. J. Green, M. Machado, J. García-de-Lomas, M. Cristo, L. Cancela da Fonseca, D. Frisch, J. L. Pérez-Bote \& A. K. Hundsdoerfer, 2010. Phylogeny, molecular ecology and taxonomy of southern Iberian lineages of Triops mauritanicus (Crustacea: Notostraca). Organisms Diversity \& Evolution 10: 409-440.

Lawton, J. H., D. E. Bignell, B. Bolton, G. F. Bloemers, P. Eggleton, P. M. Hammond, M. Hodda, R. D. Holt, T. B. Larsen, N. A. Mawdsley, N. E. Stork, D. S. Srivastava \& A. D. Watt, 1998. Biodiversity inventories, indicator taxa and effects of habitat modification in tropical forest. Nature 391: 72-76.

Legendre, P., 2012. Numerical Ecology, 3rd edition.

Lumbreras, A., H. Tahiri, C. Pinto-Cruz, C. Pardo \& J. A. Molina, 2012. Habitat variation in vernal pool ecosystems on both sides of the Strait of Gibraltar. Journal of Coastal Research 28: 1032-1039.

Lumbreras, A., C. Pardo \& J. A. Molina, 2013. Bioindicator role of aquatic Ranunculus in Mediterranean freshwater habitats. Aquatic Conservation: Marine and Freshwater Ecosystems 23: 582-593.

Maes, J., 2013. A model for the assessment of habitat conservation status in the EU: European Union.

Maes, J., M. L. Paracchini, G. Zulian, M. B. Dunbar \& R. Alkemade, 2012. Synergies and trade-offs between ecosystem service supply, biodiversity, and habitat conservation status in Europe. Biological Conservation 155: $1-12$.

McGeoch, M. A. \& S. L. Chown, 1998. Scaling up the value of bioindicators. Trends in Ecology \& Evolution 13: 46-47.
Neto, C., J. Capelo, C. Sergio \& J. C. Costa, 2007. The Adiantetea class on the cliffs of SW Portugal and of the Azores. Phytocoenologia 37: 221-237.

Oertli, B., J. Biggs, R. Céréghino, P. Grillas, P. Joly \& J.-B. Lachavanne, 2005. Conservation and monitoring of pond biodiversity: introduction. Aquatic Conservation: Marine and Freshwater Ecosystems 15: 535-540.

Oertli, B., R. Céréghino, A. Hull \& R. Miracle, 2009. Pond conservation: from science to practice. Hydrobiologia 634: $1-9$.

Paupério, J., J. S. Herman, J. Melo-Ferreira, M. Jaarola, P. C. Alves \& J. B. Searle, 2012. Cryptic speciation in the field vole: a multilocus approach confirms three highly divergent lineages in Eurasia. Molecular Ecology 21: 6015-6032.

Pinto-Cruz, C., A. M. Barbosa, J. A. Molina \& M. D. EspíritoSanto, 2011. Biotic and abiotic parameters that distinguish types of temporary ponds in a Portuguese Mediterranean ecosystem. Ecological Indicators 11: 1658-1663.

Pinto-Cruz, C., J. A. Molina, M. Barbour, V. Silva \& M. D. Espírito-Santo, 2009. Plant communities as a tool in temporary ponds conservation in SW Portugal. Hydrobiologia 634: 11-24.

Pita, R., A. Mira \& P. Beja, 2006. Conserving the Cabrera vole, Microtus cabrerae, in intensively used Mediterranean landscapes. Agriculture, Ecosystems \& Environment 115: $1-5$.

Rhazi, L., P. Grillas, A. M. Toure \& L. T. Ham, 2001. Impact of land use in catchment and human activities on water, sediment and vegetation. Life Sciences 324: 165-177.

Rhazi, L., M. Rhazi, P. Grillas \& D. El Khyari, 2006. Richness and structure of plant communities in temporary pools from western Morocco: influence of human activities. Hydrobiologia 570: 197-203.

Rhazi, L., P. Grillas, E.-R. Saber, M. Rhazi, L. Brendonck \& A. Waterkeyn, 2011. Vegetation of Mediterranean temporary pools: a fading jewel? Hydrobiologia 689: 1-14.

Rosset, V., S. Angélibert, F. Arthaud, G. Bornette, J. Robin, A. Wezel, D. Vallod \& B. Oertli, 2014. Is eutrophication really a major impairment for small waterbody biodiversity? Journal of Applied Ecology 51: 415-425.

Ruiz, E., 2008. Management of Natura 2000 habitats. 3170* Mediterranean temporary ponds. European Commission.

Sala, J., S. Gascón, D. Boix, J. Gesti \& X. D. Quintana, 2004. Proposal of a rapid methodology to assess the conservation status of Mediterranean wetlands and its application in Catalunya (NE Iberian Peninsula). Archives des Sciences 57: 141-152.

Sand-Jensen, K., T. Riis, O. Vestergaard \& S. Larsen, 2000. Macrophyte decline in Danish lakes and streams over the past 100 years. Journal of Ecology 88: 1030-1040.

Serrano, L. \& M. Zunzunegui, 2008. The relevance of preserving temporary ponds during drought: hydrological and vegetation changes over a 16-year period in the Doñana National Park (south-west Spain). Aquatic Conservation: Marine and Freshwater Ecosystems 18: 261-279.

Stamati, F., N. Nikolaidis, E. Dimitriou, N. Skoulikidis \& T. Koussouris, 2008. Hydro-geochemical aspects of a typical Mediterranean temporary pond in western Crete (Omalos Plateau). Journal of Environmental Quality 37: 164-173. 
Stork, N. E., T. J. B. Boyle, V. Dale, H. Eeley, B. Finegan, M. Lawes \& N. Manokaran, 1997. Criteria and indicators for assessing the sustainability of forest management: conservation of biodiversity. CIFOR Working Paper 17.

Trigal, C., F. García-Criado \& C. Fernández-Aláez, 2009. Towards a multimetric index for ecological assessment of Mediterranean flatland ponds: The use of macroinvertebrates as bioindicators. Hydrobiologia 618: 109-123.

Urban, N. A., R. K. Swihart, M. C. Malloy \& J. B. Dunning, 2012. Improving selection of indicator species when detection is imperfect. Ecological Indicators 15: 188-197.
Van den Broeck, M., A. Waterkeyn, L. Rhazi, P. Grillas \& L. Brendonck, 2015. Assessing the ecological integrity of endorheic wetlands, with focus on Mediterranean temporary ponds. Ecological Indicators 54: 1-11.

Waterkeyn, A., P. Grillas, B. Vanschoenwinkel \& L. Brendonck, 2008. Invertebrate community patterns in Mediterranean temporary wetlands along hydroperiod and salinity gradients. Freshwater Biology 53: 1808-1822.

Zacharias, I. \& M. Zamparas, 2010. Mediterranean temporary ponds. A disappearing ecosystem. Biodiversity and Conservation 19: 3827-3834. 